\title{
Kajian Emisi Kendaraan di Persimpangan Surabaya Tengah dan Timur serta Potensi Pengaruh terhadap Kesehatan Lingkungan Setempat
}

\author{
Handy Gunawan ${ }^{1}$ \\ Program Studi Teknik Sipil, Fakultas Teknik Sipil dan Perencanaan \\ Universitas Kristen Petra, Surabaya, Indonesia
}

\section{Gogot Setyo Budi}

Program Studi Teknik Sipil, Fakultas Teknik Sipil dan Perencanaan

Universitas Kristen Petra, Surabaya, Indonesia

Artikel Masuk : 4 Maret 2017

Artikel Diterima : 25 April 2017

Tersedia Online : 29 Agustus 2017

\begin{abstract}
Abstrak: Pertambahan jumlah kendaraan bermotor di jalan akan meningkatkan konsumsi bahan bakar minyak (BBM). Pada skala nasional, konsumsi BBM meningkat dari 62.034.065 kiloliter pada tahun 2013 menjadi 70.744 .977 kiloliter pada tahun 2014. Selain menguras kandungan energi fosil yang tidak tergantikan, peningkatan konsumsi BBM tersebut juga berdampak langsung pada lingkungan akibat bertambahnya produksi emisi gas buang. Konsentrasi $\mathrm{CO}$ atau $\mathrm{CO}_{2}, \mathrm{HC}, \mathrm{NOx}, \mathrm{PM}$, dan $\mathrm{SO}_{2}$ di titik-titik dengan kepadatan lalu-lintas tinggi, seperti persimpangan jalan (traffic light) relatif lebih besar karena penumpukan volume kendaraan. Penelitian ini bertujuan untuk mengetahui kebutuhan BBM dan emisi gas buang dari kendaraan bermotor di persimpangan jalan yang dilengkapi dengan lampu lalu-lintas, serta pengaruhnya terhadap lingkungan sekitar. Penelitian ini dilakukan dengan mengamati volume kendaraan di dua lokasi di Surabaya pada durasi dua jam sibuk, yaitu mulai jam 6.20 sampai jam 8.20 kemudian mengkonversikan emisi gas buang dan BBM yang dikonsumsi dari jumlah kendaraan yang ada. Hasil penelitian menunjukkan bahwa volume BBM yang dikonsumsi di satu arah jalan di persimpangan pada durasi dua jam adalah 700 liter dan emisi $\mathrm{PM}, \mathrm{NO}, \mathrm{SO}_{2}$ yang dihasilkan adalah 353 gram, 15.166 gram, dan 410 gram. Konsentrasi $\mathrm{NO}$ dan $\mathrm{SO}_{2}$ di perempatan Jalan Dr. Soetomo setelah satu jam emisi adalah $3059 \mu \mathrm{g} / \mathrm{m}^{3}$ dan $57 \mu \mathrm{g} / \mathrm{m}^{3}$, sedangkan di perempatan Jalan Kertajaya masing-masing adalah $672 \mu \mathrm{g} / \mathrm{m}^{3}$ dan $12 \mu \mathrm{g} / \mathrm{m}^{3}$. Jumlah polutan tersebut jauh di atas ambang batas toleransi bagi kesehatan manusia, seperti yang disyaratkan oleh WHO, yaitu kurang dari $40 \mu \mathrm{g} / \mathrm{m}^{3}$ untuk NO dan $20 \mu \mathrm{g} / \mathrm{m}^{3}$ untuk SO . $_{2}$
\end{abstract}

Kata Kunci: konsumsi BBM, kendaraan bermotor, emisi gas buang

Abstract: The growing number of motor vehicles on the street will increase the consumption of gasoline. At the national scale, gasoline consumption increased from 62.035.065 kiloliters in 2013 to 70.744 .977 kiloliters in 2014. The increasing consumption of gasoline not only drains the non-renewable fossil energy but also affects the environment due to gas emission

\footnotetext{
${ }^{1}$ Korespondensi Penulis: Program Studi Teknik Sipil, Fakultas Teknik Sipil dan Perencanaan, Universitas Kristen Petra, Surabaya Email: handygunawan17@gmail.com
} 


\section{Kajian Emisi Kendaraan di Persimpangan Surabaya Tengah dan Timur serta Potensi Pengaruh...}

generated by fuel burning. The carbon monoxide $(\mathrm{CO})$ or carbon dioxide $\left(\mathrm{CO}_{2}\right)$, hydrocarbon $(\mathrm{HC})$, nitrogen oxide ( $\left.\mathrm{No}_{x}\right)$, particulate matter (PM), and sulfide $\left(\mathrm{SO}_{2}\right)$ concentration in a congestion area such as the area around traffic lights is substantially high. This research aims to find the gasoline consumption and emission rate in intersections with traffic lights, and its effect on surrounding environment. The research was done by collecting traffic volume in two locations in Surabaya, at morning rush hours, which started from 6.20 A.M. to 8.20 A.M, then calculated the emission rate and gasoline consumption from traffic data. The data showed that the volume of gasoline consumed in one lane (out of four lanes) at the traffic lights for two-hour duration was 700 liters, and the total substance of PM, NO, SO $\mathrm{S}_{2}$ produced were 353 grams, 15.166 grams, and 410 grams. The concentration of $\mathrm{NO}$ and $\mathrm{SO}_{2}$ at Dr. Soetomo intersection after one-hour emission was $3059 \mu \mathrm{g} / \mathrm{m}^{3}$ and $57 \mu \mathrm{g} / \mathrm{m}^{3}$, while that at Kertajaya intersection was $672 \mu \mathrm{g} / \mathrm{m}^{3}$ and $12 \mu \mathrm{g} / \mathrm{m}^{3}$, respectively. These pollutants were away above the tolerable limit to human health as suggested by WHO, which should not exceed $50 \mu \mathrm{g} / \mathrm{m}^{3}$ for PM, 40 $\mu \mathrm{g} / \mathrm{m}^{3}$ for $\mathrm{NO}_{3}$ for $\mathrm{NO}$, and $20 \mu \mathrm{g} / \mathrm{m} 3$ for $\mathrm{SO}_{2}$.

Keywords: gasoline consumption, gas emission, motorized vehicle

\section{Pendahuluan}

Pertumbuhan jumlah armada transportasi semakin meningkat. Jumlah kendaraan di Indonesia pada tahun 2014 berdasarkan jenisnya adalah 12.599 .038 unit mobil penumpang, 2.398.846 unit bis, 6.235.136 unit mobil barang, dan 92.976.240 unit sepeda motor. Pertumbuhan rata-rata jumlah setiap kendaraan sudah mencapai $10,39 \%$ per tahunnya. Pertumbuhan jumlah kendaraan tersebut tidak sebanding dengan penambahan infrastruktur jalan seperti lampu lalu-lintas, pelebaran jalan, persimpangan jalan yang lebih teratur sehingga kondisi jalan menjadi kurang memadai (Badan Pusat Statistik Indonesia, 2014)

Jumlah kendaraan yang berada di jalan meningkat pesat pada jam-jam tertentu, terutama pada jam sibuk. Peningkatan ini menyebabkan terjadinya antrian panjang pada persimpangan meskipun sudah diatur menggunakan lampu lalu-lintas. Antrian di persimpangan akibat pengaturan lampu lalu-lintas merupakan salah satu faktor meningkatnya konsumsi BBM.

Antrian kendaraan yang panjang di persimpangan atau kemacetan lalu-lintas dapat menyebabkan terganggunya aktivitas pekerjaan, sehingga jam efektif kerja dapat berkurang. Selain itu, dampak yang ditimbulkan adalah meningkatnya polusi udara sekitar daerah antrian. Hal ini dapat menimbulkan dampak negatif yang berkaitan dengan kesehatan kepada penduduk sekitar, pengendara sepeda motor, atau pejalan kaki. Oleh karena itu, daerah persimpangan harus lebih mendapat perhatian karena jumlah antrian kendaraaan yang cenderung bertambah dan waktu antrian yang lebih lama.

Beberapa penelitian tentang gas buang kendaraan telah dilakukan sebelumnya. Perhitungan jumlah bahan bakar yang digunakan berdasarkan waktu tundaan (idle) kendaraan dan panjang antrian di pintu perlintasan kereta api telah diteliti oleh Hadis \& Sumarsono (2013) dan hal ini dapat menjadi tolok ukur jumlah konsumsi bahan bakar secara umum. Perhitungan jumlah gas buang berdasarkan konsumsi bahan bakar regional Surabaya sudah dilakukan oleh Ismayanti, Boedisantoso, \& Assomadi (2010). Gambar 1 menunjukkan bahwa gas $\mathrm{CO}_{2}$ yang dihasilkan meningkat dari 1.204 .368 ton pada tahun 2000 menjadi 1.851.857 ton pada tahun 2010. Berdasarkan perkiraan, gas $\mathrm{CO}_{2}$ yang dihasilkan akan menjadi 2.514.242 ton pada tahun 2020. Pada saat ini, standar emisi yang dipergunakan di Indonesia masih mengacu pada standar Euro 2 seperti yang dijelaskan pada Tabel 1 (Ismayanti, Boedisantoso, \& Assmoadi, 2010). Standar ini masih sangat rendah karena beberapa negara sudah menggunakan Euro 4 dan 5. 
Tujuan dari penelitian ini adalah untuk meneliti tingkat dan potensi dari efek emisi gas buang yang ada di beberapa persimpangan di Surabaya, yang menggunakan lampu lalulintas. Penelitian dititikberatkan pada saat jam sibuk yang mengakibatkan antrian yang panjang.

Lokasi pengumpulan data dilakukan di dua lokasi yang mewakili area Surabaya Tengah dan Surabaya Timur, dengan melihat jumlah kendaraan yang melewati lampu lalulintas setiap interval waktu tertentu. Jumlah kendaraan dan lama tundaan kendaraan yang antri setiap jamnya dihitung berdasarkan panjang antrian. Data panjang antrian didapatkan dari situs peta online seperti Google Maps. Durasi waktu tundaan dan kecepatan rata-rata selanjutnya digunakan untuk mengetahui konsumsi bahan bakar kendaraan dan emisi yang dihasilkan oleh kendaraan (Isnaeni \& Lubis, 2003).

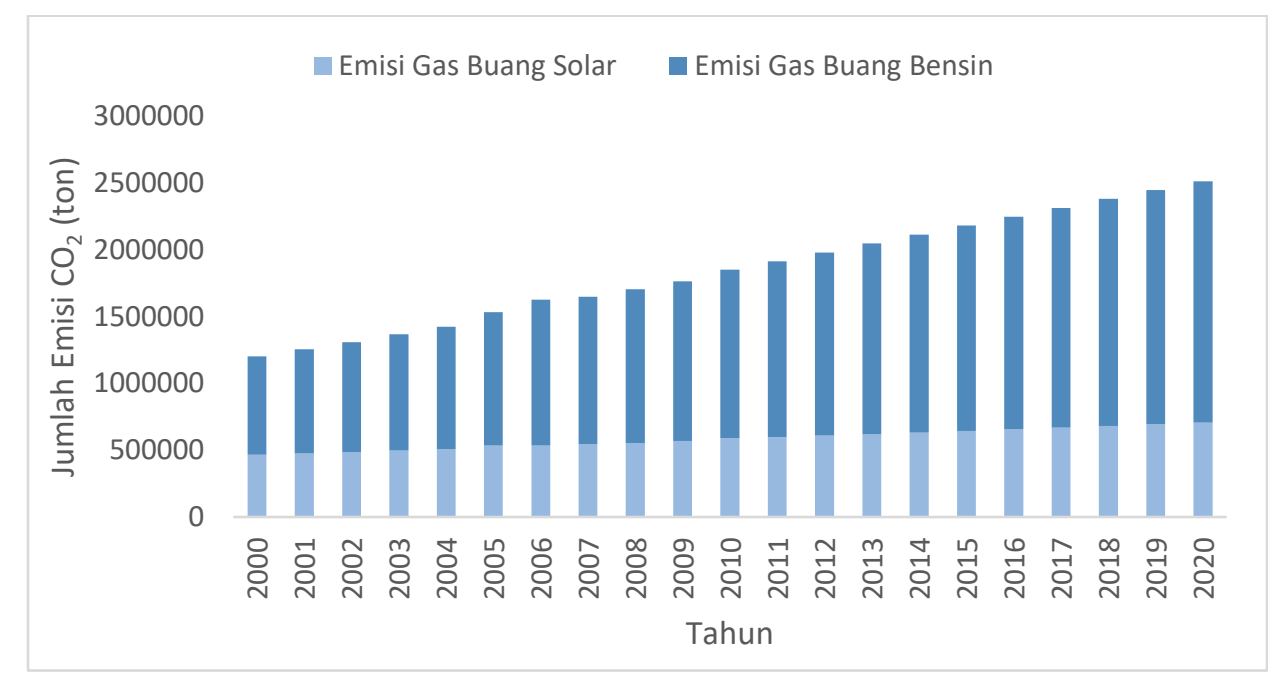

Sumber: Ismayanti et al., 2010

Gambar 1. Emisi Carbon Dioxida( $\left.\mathrm{CO}_{2}\right)$ dari Bahan Bakar Bensin dan Solar Tahun 2000-2010

Tabel 1. Faktor Emisi Berdasarkan Jenis Kendaraan

\begin{tabular}{lccccc}
\hline Jenis & $\mathbf{C O}(\mathbf{g} / \mathbf{k m})$ & $\mathbf{H C}(\mathbf{g} / \mathbf{k m})$ & $\mathbf{N O x}(\mathbf{g} / \mathbf{k m})$ & $\mathbf{P M}_{\mathbf{1 0}}(\mathbf{g} / \mathbf{k m})$ & $\mathbf{S O}_{2}(\mathbf{g} / \mathbf{k m})$ \\
\hline Kendaraan & 14 & 5,9 & 0,29 & 0,24 & 0,008 \\
Sepeda Motor & 40 & 4 & 2 & 0,01 & 0,026 \\
Mobil (bensin) & 2,8 & 0,2 & 3,5 & 0,53 & 0,44 \\
Mobil (solar) & 11 & 1,3 & 11,9 & 1,4 & 0,93 \\
Bis & 8,4 & 1,8 & 17,7 & 1,4 & 0,82 \\
Truk & & &
\end{tabular}

Sumber: Suhadi \& Febrina, 2013

\section{Metode Penelitian}

Volume kendaraan dan jam macet didapatkan melalui observasi situs online Google Maps (2016), dan dikonfirmasi dengan observasi lapangan. Pengumpulan data lalu-lintas dilakukan di persimpangan antara Jalan Dr. Soetomo dengan Jalan Raya Diponegoro (mewakili Surabaya Tengah) dan di persimpangan antara Jalan Kertajaya dengan Jalan Dharmawangsa di wilayah Surabaya Timur. Waktu pengumpulan dilakukan selama dua hari 


\section{Kajian Emisi Kendaraan di Persimpangan Surabaya Tengah dan Timur serta Potensi Pengaruh...}

kerja, dimulai dari pukul 6.30 sampai 8.30 pagi, masing-masing pada tanggal 14 dan 21 April 2016.

Data volume kendaraan didapatkan dengan mencatat jumlah kendaraan yang melewati persimpangan berdasarkan arah asal dan tujuan dalam kurun waktu lima menit. Contoh lokasi peninjauan volume kendaraan terdapat di Gambar 2 dan Gambar 3. Panjang antrian yang didapatkan dari Google Maps (2016), dihitung setiap interval 10 menit dan diperiksa dengan melihat panjang antrian di persimpangan tersebut. Garis jingga menandakan bahwa terjadi penurunan kecepatan dan antrian, sedangkan garis hijau menandakan tidak ada hambatan dalam perjalanan. Perhitungan difokuskan pada jalan dengan volume antrian terbesar di persimpangan tersebut.

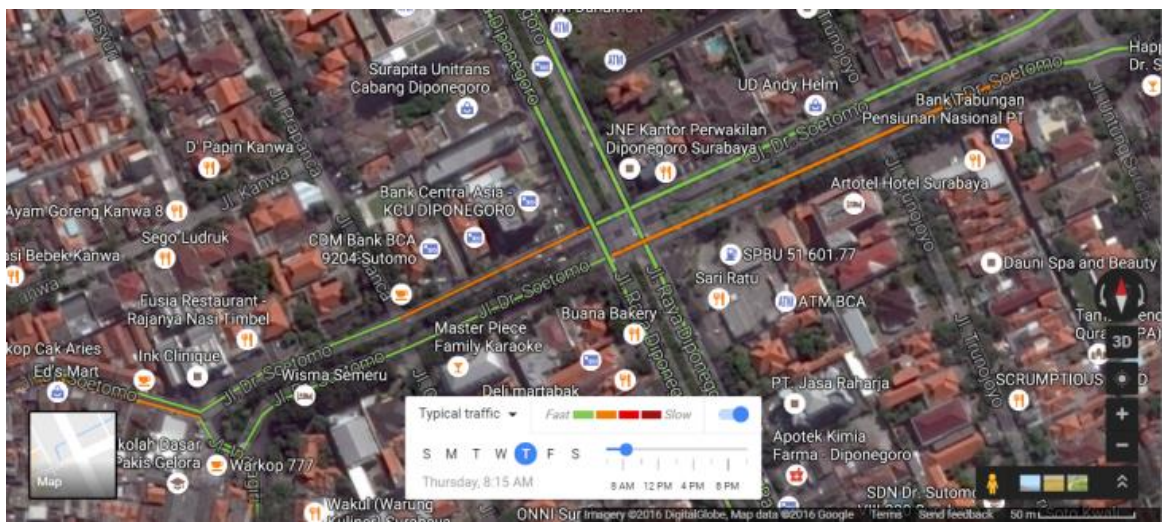

Sumber: Google Maps, 2016

Gambar 2. Peta Kemacetan di Jalan Dr. Soetemo

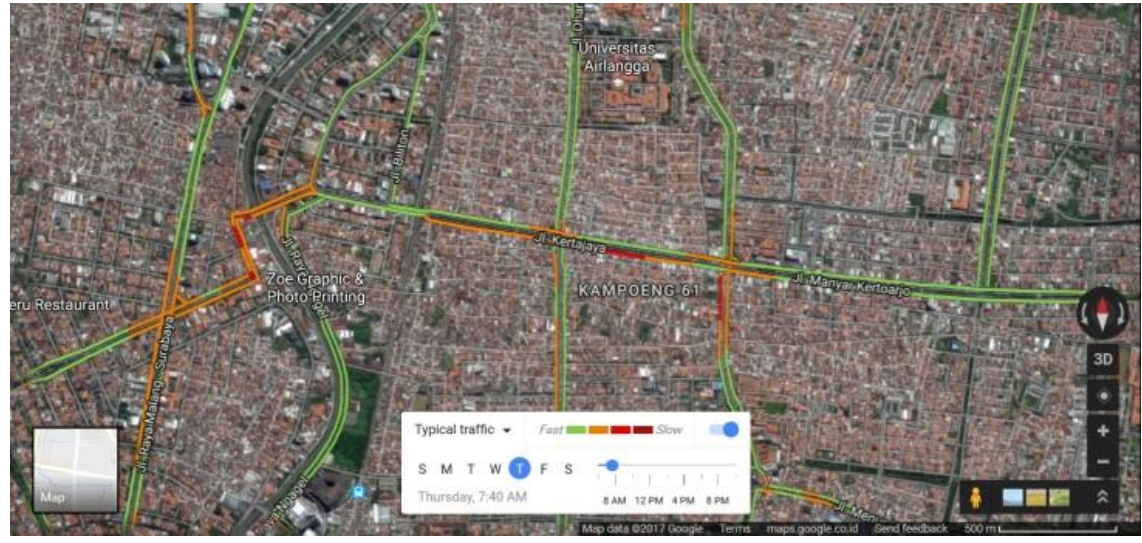

Sumber: Google Maps, 2016

\section{Gambar 3. Peta Kemacetan di Jalan Kertajaya}

Konsumsi bahan bakar dihitung berdasarkan persamaan yang dipublikasikan oleh LAPI-ITB (Isnaeni \& Lubis, 2003). Formulasi konsumsi bahan bakar tersebut dibagi menjadi tiga kondisi kendaraan, yaitu diam (idle), berakselerasi/deselerasi, dan bergerak. Konsumsi 
BBM saat akselerasi/deselerasi tidak signifikan, sehingga dapat diabaikan. Persamaan yang dipublikasikan oleh LAPI-ITB tersebut adalah :

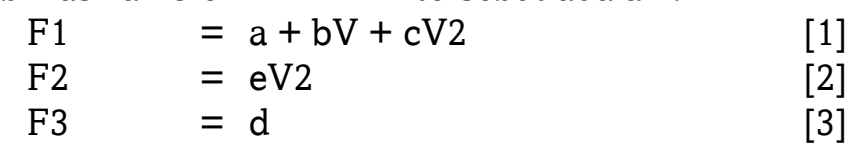

Keterangan :

F1 = Konsumsi BBM pada saat bergerak dengan kecepatan konstan, [liter/100 satuan mobil penumpang (smp) per km]

F2 = Konsumsi BBM pada saat akselerasi/deselerasi (liter/smp)

F3 = Konsumsi BBM pada saat idle (liter/smp per jam)

$\mathrm{V}=$ Kecepatan kendaraan $(\mathrm{km} / \mathrm{jam})$

Konstanta :

$\begin{array}{ll}\mathrm{a} & =170.10-1 \\ \mathrm{~b} & =-455.10-3 \\ \mathrm{c} & =490.10-5 \\ \mathrm{~d} & =140.10-2 \\ \mathrm{e} & =770.10-8\end{array}$

Jumlah emisi gas buang $\mathrm{CO} 2$ dihitung berdasarkan Intergovernmental Panel on Climate Change (Maurice et al., 2006) dan Aubé (2001) sebagai berikut:

$\mathrm{CO} 2=\mathrm{F} \times \mathrm{Ex} 10-9$ ton $/ \mathrm{l}$

Keterangan :

$\mathrm{F}=$ Faktor emisi $(69300 \mathrm{~kg} / \mathrm{TJ}$ untuk bensin dan $74100 \mathrm{~kg} / \mathrm{TJ}$ untuk solar $)$

$\mathrm{E}=$ Nilai energi ( $34.66 \mathrm{MJ} / \mathrm{l}$ untuk bensin dan $38.68 \mathrm{MJ} / \mathrm{l}$ untuk solar )

Sehingga jumlah emisi yang dihasilkan adalah :

$\mathrm{CO} 2=0.002471238($ ton $/ \mathrm{l})$ untuk bensin

$\mathrm{CO} 2=0.002866188($ ton $/ \mathrm{l})$ untuk solar

Jumlah emisi gas buang lainnya dihitung berdasarkan panduan konsumsi bahan bakar rata-rata kendaraan penumpang (United States Environmental Protection Agency, 2008), yaitu sebesar 10,2468 km/liter. Data ini kemudian dikorelasikan dengan Tabel 1 dan menghasilkan Tabel 2 yang dapat digunakan untuk menghitung emisi gas buang kendaraan. Konsentrasi emisi gas buang $\mathrm{NO}$ dan $\mathrm{SO}_{2}$ dihitung menggunakan Meti-Lis dengan model gaussian plume. Penggunaan Meti-Lis disarankan karena hasilnya tidak menyimpang dari pengujian lapangan (Dragomir et al., 2015; Higashino, Mita, Yoshikado, Iwata, \& Nakanishi, 2007; Md Habib Al Razi \& Hiroshi, 2012). Data meteorologi yang digunakan berupa suhu sebesar $31^{\circ} \mathrm{C}$ dengan kecepatan angin sebesar $3,5 \mathrm{~m} / \mathrm{s}$ dengan sudut datang $70^{\circ}$ serta kelas stabilitas DD. Data ini didapat dari National Oceanic and Atmospheric Administration (2016) dengan data tanggal 21 Agustus 2016.

Tabel 2. Faktor Emisi Jenis Kendaraan Berdasarkan Konsumsi Bahan Bakar

\begin{tabular}{lccccc}
\hline \multicolumn{1}{c}{ Kategori } & CO & HC & NO & PM & $\mathbf{S O}_{2}$ \\
Sepeda Motor & 143,4 & 60,5 & 2,9 & 2,5 & 0,08 \\
Mobil Bensin & 409,8 & 40,9 & 20,5 & 0,1 & 0,3 \\
Mobil Solar & 28,6 & 2,0 & 35,9 & 5,4 & 4,5 \\
Bis & 112,7 & 13,3 & 121,9 & 14,3 & 9,5 \\
Truk & 86,1 & 18,4 & 181,4 & 14,3 & 8,4 \\
\hline
\end{tabular}

Sumber: Suhadi \& Febrina, 2013 


\section{Data dan Analisis}

Volume kendaraan dan jam macet didapatkan melalui observasi situs online Google Maps (2016) dan dikonfirmasi dengan observasi lapangan. Pengumpulan data lalu-lintas dilakukan di persimpangan antara jalan Dr. Soetomo dengan Raya Diponegoro (mewakili Surabaya Tengah) dan di persimpangan antara Jalan Kertajaya dengan Jalan Dharmawangsa di wilayah Surabaya Timur. Waktu pengumpulan dilakukan selama dua hari kerja, dimulai dari pukul 6.30 sampai 8.30 pagi, masing-masing pada tanggal 14 dan 21 April 2016.

Tabel 3. Panjang Antrian dan Volume Lewatan kendaraan di Jalan Dr. Soetomo dan Jalan Kertajaya

\begin{tabular}{|c|c|c|c|c|c|c|c|c|}
\hline \multirow{3}{*}{ JAM } & \multicolumn{2}{|c|}{ Volume lewatan } & \multicolumn{2}{|c|}{ Volume antrian } & \multicolumn{2}{|c|}{ Volume lewatan } & \multicolumn{2}{|c|}{ Volume antrian } \\
\hline & \multicolumn{4}{|c|}{$\begin{array}{c}\text { Jalan Dr. Soetomo dari Arah Timur ke } \\
\text { Barat }\end{array}$} & \multicolumn{4}{|c|}{$\begin{array}{l}\text { Jalan Kertajaya dari Arah Timur ke } \\
\text { Barat }\end{array}$} \\
\hline & Roda 2 & Roda 4 & Roda 2 & Roda 4 & Roda 2 & Roda 4 & Roda 2 & Roda 4 \\
\hline 6.30 & 193 & 42 & 449 & 98 & 77 & 52 & 66 & 44 \\
\hline 6.35 & 351 & 36 & 953 & 98 & 188 & 85 & 98 & 44 \\
\hline 6.40 & 478 & 36 & 1298 & 98 & 120 & 60 & 89 & 44 \\
\hline 6.45 & 482 & 78 & 604 & 98 & 166 & 85 & 87 & 44 \\
\hline 6.50 & 444 & 47 & 924 & 98 & 129 & 72 & 80 & 44 \\
\hline 6.55 & 349 & 55 & 620 & 98 & 105 & 55 & 85 & 44 \\
\hline 7.00 & 555 & 67 & 810 & 98 & 220 & 128 & 267 & 156 \\
\hline 7.05 & 383 & 54 & 693 & 98 & 110 & 43 & 398 & 156 \\
\hline 7.10 & 506 & 74 & 669 & 98 & 262 & 123 & 331 & 156 \\
\hline 7.15 & 344 & 38 & 885 & 98 & 118 & 61 & 301 & 156 \\
\hline 7.20 & 379 & 56 & 662 & 98 & 299 & 135 & 345 & 156 \\
\hline 7.25 & 546 & 76 & 702 & 98 & 145 & 66 & 342 & 156 \\
\hline 7.30 & 540 & 52 & 1015 & 98 & 335 & 146 & 442 & 193 \\
\hline 7.35 & 569 & 64 & 869 & 98 & 176 & 91 & 372 & 193 \\
\hline 7.40 & 623 & 69 & 883 & 98 & 187 & 91 & 396 & 193 \\
\hline 7.45 & 543 & 66 & 804 & 98 & 323 & 135 & 461 & 193 \\
\hline 7.50 & 627 & 73 & 840 & 98 & 231 & 113 & 394 & 193 \\
\hline 7.55 & 571 & 46 & 1214 & 98 & 155 & 76 & 393 & 193 \\
\hline 8.00 & 430 & 67 & 628 & 98 & 127 & 69 & 436 & 237 \\
\hline 8.05 & 454 & 56 & 793 & 98 & 255 & 130 & 465 & 237 \\
\hline 8.10 & 432 & 64 & 660 & 98 & 166 & 69 & 570 & 237 \\
\hline 8.15 & 396 & 68 & 569 & 98 & 135 & 72 & 444 & 237 \\
\hline 8.20 & 391 & 65 & 588 & 98 & 143 & 78 & 435 & 237 \\
\hline 8.25 & 344 & 48 & 701 & 98 & 127 & 68 & 443 & 237 \\
\hline
\end{tabular}

Sumber: Hasil Analisis, 2016

Volume kendaraan kemudian dikonversikan menjadi satuan mobil penumpang (smp). Satuan ini menunjukkan arus lalu-lintas dengan tipe kendaraan yang berbeda-beda dapat dikonversikan menjadi satu tipe yaitu kendaraan ringan (mobil penumpang). Satuan ini direkomendasikan oleh Manual Kapasitas Jalan Indonesia (PT. Binakarya dan SWEROAD, 1997). Faktor konversi yang digunakan untuk sepeda motor adalah $0.2 \mathrm{smp}$ sedangkan untuk 
kendaraan berat sebesar $1.3 \mathrm{smp}$. Berhubung volume kendaraan berat yang melewati Jalan Kertajaya dan Jalan Dr. Soetomo tidak ada, maka faktor konversi kendaraan berat tidak digunakan. Konversi volume menjadi satuan mobil penumpang diperlukan untuk memperkirakan volume konsumsi bahan bakar dan emisi gas buang.

Perhitungan jumlah rata-rata kendaraan yang mengantri ditentukan dari jumlah saat kendaraan mulai berhenti dan mulai bergerak. Jumlah kendaraan dikategorikan berdasarkan jenis bahan bakar yang digunakan. Penentuan jumlah kategori kendaraan tersebut diasumsi berdasarkan data yang diperoleh Dinas Pendapatan Daerah pada tahun 2010, yaitu 89.39\% mobil penumpang berbahan bakar bensin dan $10.61 \%$ mobil penumpang berbahan bakar solar (Dispenda Kota Surabaya, 2010). Data jumlah kendaraan (smp) dan rata-rata kecepatan kendaraan dapat dilihat pada Tabel 4.

Tabel 4. Kecepatan Rata-rata Kendaraan dan Volume Kendaraan Berdasarkan Bahan Bakar dalam Satuan SMP (Satuan Mobil Penumpang)

\begin{tabular}{ccccccc}
\hline & \multicolumn{3}{c}{ Kecepatan Rata-rata } & \multicolumn{3}{c}{ Volume Kendaraan dalam smp } \\
\cline { 2 - 7 } JAM & $\begin{array}{c}\text { Jalan } \\
\text { Kertajaya } \\
\text { (Km/Jam) }\end{array}$ & $\begin{array}{c}\text { Jalan Dr. } \\
\text { Soetomo } \\
(\text { Km/Jam) }\end{array}$ & $\begin{array}{c}\text { Jalan Dr. Soetomo } \\
\text { Bensin } \\
\text { (smp) }\end{array}$ & $\begin{array}{c}\text { Solar } \\
(\mathbf{s m p})\end{array}$ & $\begin{array}{c}\text { Jensin } \\
\text { (smp) }\end{array}$ & $\begin{array}{c}\text { Solar } \\
\text { (smp) }\end{array}$ \\
\hline 6.30 & 4 & 4 & 139 & 8 & 26 & 2 \\
6.35 & 7 & 3 & 227 & 8 & 30 & 2 \\
6.40 & 5 & 3 & 283 & 8 & 29 & 2 \\
6.45 & 7 & 7 & 125 & 6 & 29 & 2 \\
6.50 & 6 & 4 & 207 & 8 & 28 & 2 \\
6.55 & 5 & 5 & 152 & 7 & 28 & 2 \\
7.00 & 11 & 6 & 164 & 7 & 113 & 10 \\
7.05 & 4 & 5 & 164 & 8 & 188 & 14 \\
7.10 & 10 & 6 & 137 & 6 & 124 & 10 \\
7.15 & 5 & 3 & 213 & 8 & 160 & 13 \\
7.20 & 12 & 5 & 157 & 7 & 118 & 9 \\
7.25 & 6 & 6 & 139 & 6 & 163 & 13 \\
7.30 & 12 & 4 & 213 & 8 & 162 & 13 \\
7.35 & 8 & 5 & 176 & 7 & 188 & 16 \\
7.40 & 8 & 6 & 171 & 7 & 192 & 16 \\
7.45 & 12 & 6 & 164 & 7 & 172 & 13 \\
7.50 & 10 & 6 & 160 & 7 & 177 & 14 \\
7.55 & 6 & 4 & 252 & 8 & 201 & 16 \\
8.00 & 6 & 6 & 140 & 7 & 256 & 21 \\
8.05 & 11 & 5 & 176 & 7 & 221 & 18 \\
8.10 & 6 & 5 & 148 & 7 & 279 & 21 \\
8.15 & 6 & 6 & 131 & 7 & 255 & 21 \\
8.20 & 7 & 6 & 137 & 7 & 250 & 21 \\
8.25 & 6 & 4 & 172 & 8 & 257 & 22 \\
\hline & 6 & 5 & & & &
\end{tabular}

Sumber: Hasil Analisis, 2016

Besarnya konsumsi bahan bakar, emisi $\mathrm{CO}_{2}$, emisi $\mathrm{CO}$, dan emisi lain seperti $\mathrm{HC}$, NO, $\mathrm{PM}$, dan $\mathrm{SO}_{2}$ pada interval waktu pencatatan dapat dilihat di Gambar 4, Gambar 5, dan Gambar 6. Total emisi yang dihasilkan selama jam 6.20 hingga 8.20 di persimpangan Jalan 
Kertajaya sendiri adalah sebesar 1.752 ton $\mathrm{CO}_{2}, 267.001$ gram $\mathrm{CO}, 26.657$ gram $\mathrm{HC}, 15.166$ gram NO, 352 gram $\mathrm{PM}$, dan 410 gram $\mathrm{SO}_{2}$, sedangkan konsumsi BBM mencapai 700 liter. Rata-rata emisi $\mathrm{NO}$ dan $\mathrm{SO}_{2}$ yang dihasilkan di persimpangan Jalan Kertajaya pada saat sibuk masing-masing adalah sebesar 500 gram dan 10 gram per lima menit dengan panjang antrian rata-rata sebesar 350 meter. Sementara itu, di Jalan Dr. Soetomo tercatat rata-rata emisi NO dan $\mathrm{SO}_{2}$ sebesar 568 gram dan 12 gram per lima menit dengan panjang antrian rata-rata 220 meter.

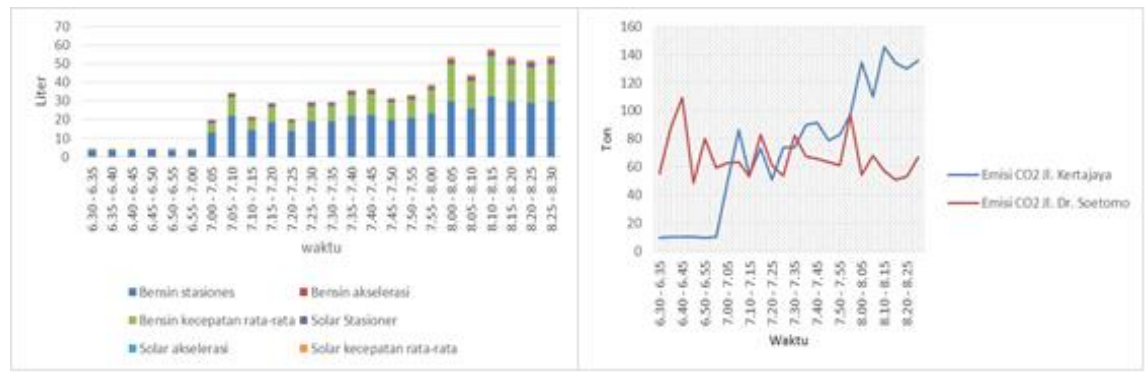

Sumber: Hasil Analisis, 2016

Gambar 4. Total Konsumsi Berdasarkan Posisi Kendaraan dan Emisi CO2 Kendaraan Berdasarkan Waktu

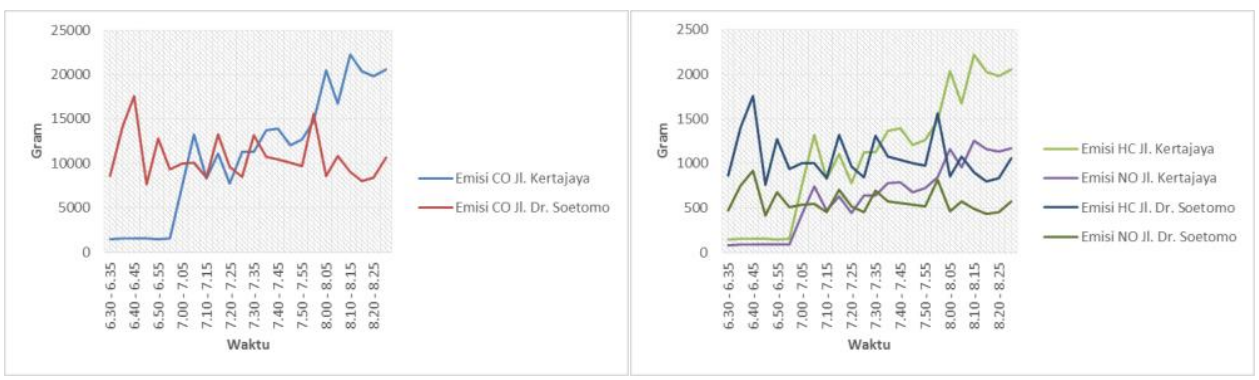

Sumber: Hasil Analisis, 2016

\section{Gambar 5. Total Emisi CO, HC dan NO Berdasarkan Waktu}

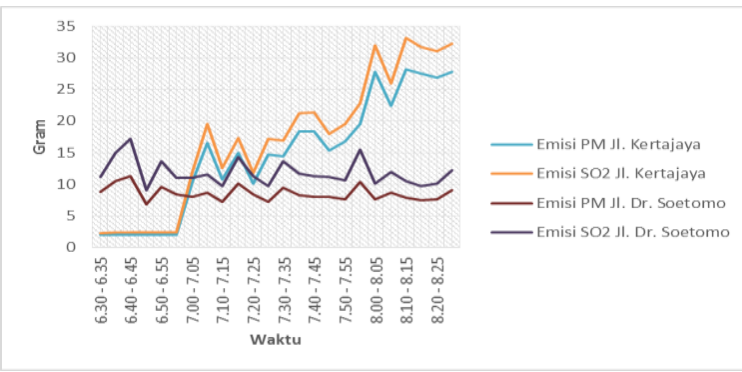

Sumber: Hasil Analisis, 2016

Gambar 6. Total Emisi PM dan $\mathrm{SO}_{2}$ 
Konsentrasi $\mathrm{NO}$ dan $\mathrm{SO}_{2}$ diperhitungkan di dua tempat, yaitu di muka lampu merah perempatan dan di depan bangunan sekitar Jalan Dr. Soetomo yang mempunyai konsentrasi NO sebesar $3059 \mu \mathrm{g} / \mathrm{m}^{3}$ dan $\mathrm{SO}_{2}$ sebesar $57 \mu \mathrm{g} / \mathrm{m}^{3}$ di muka perempatan, serta NO 278 $\mu \mathrm{g} / \mathrm{m}^{3}$ dan $\mathrm{SO}_{2}$ sebesar $17 \mu \mathrm{g} / \mathrm{m}^{3}$ di depan gedung sekitar. Jalan Kertajaya mempunyai konsentrasi NO sebesar $672 \mu \mathrm{g} / \mathrm{m}^{3}$ serta $\mathrm{SO}_{2} 12 \mu \mathrm{g} / \mathrm{m}^{3}$ di muka perempatan dan NO sebesar $637 \mu \mathrm{g} / \mathrm{m}^{3}$ dan $\mathrm{SO}_{2} 20 \mu \mathrm{g} / \mathrm{m}^{3}$ di depan gedung sekitar. Konsentrasi $\mathrm{NO}$ dan $\mathrm{SO}_{2}$ yang sangat besar di Jalan Dr. Soetomo dapat terjadi karena arah angin yang sejajar dengan ruas jalan. Sementara itu, konsentrasi NO yang besar dibandingkan dengan $\mathrm{SO}_{2}$ disebabkan oleh faktor emisi yang tinggi. Pada penelitian ini, tidak memberikan tingkat konsentrasi PM. Peta persebaran $\mathrm{NO}$ dan $\mathrm{SO}_{2}$ dapat dilihat di Gambar 7, Gambar 8, Gambar 9, dan Gambar 10 yaitu konsentrasi $\mathrm{NO}$ dan $\mathrm{SO}_{2}$ terbesar berada di dekat sumber dan mengecil jika menjauh dari sumber yang diidealisasikan sebagai garis di antara dua titik hitam.

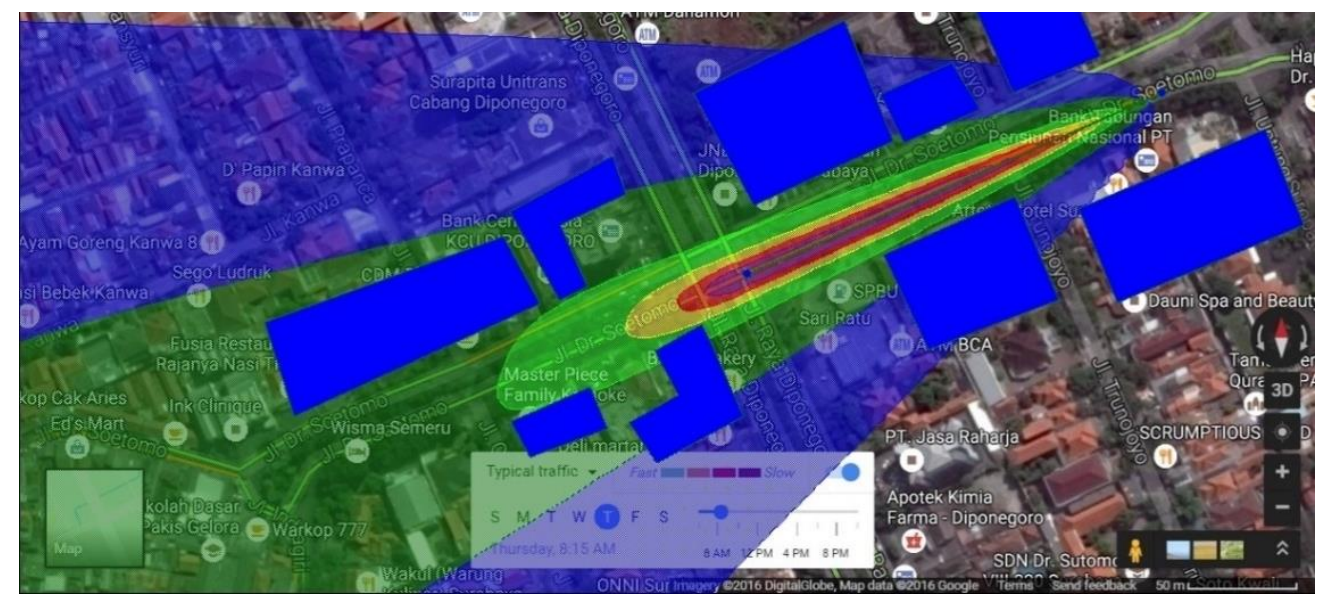

Sumber: Hasil Analisis, 2016

Gambar 7. Peta Konsentrasi NO di Jalan Dr. Soetomo

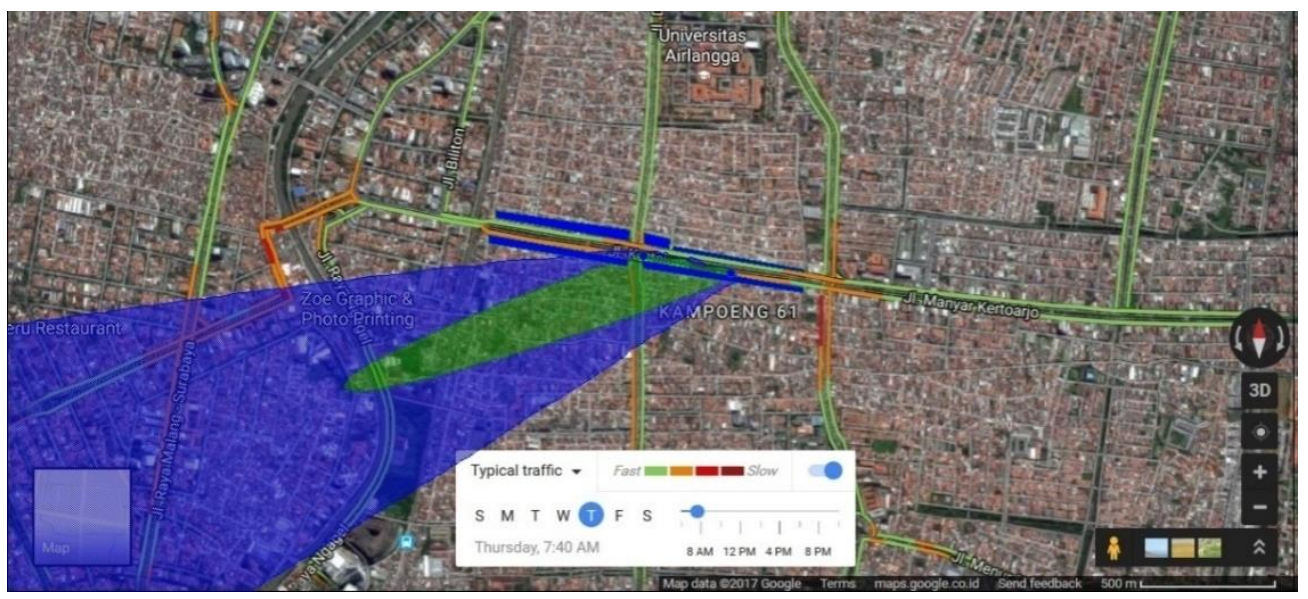

Sumber: Hasil Analisis, 2016

Gambar 8. Peta Konsentrasi NO di Jalan Kertajaya 
122 Kajian Emisi Kendaraan di Persimpangan Surabaya Tengah dan Timur serta Potensi Pengaruh...

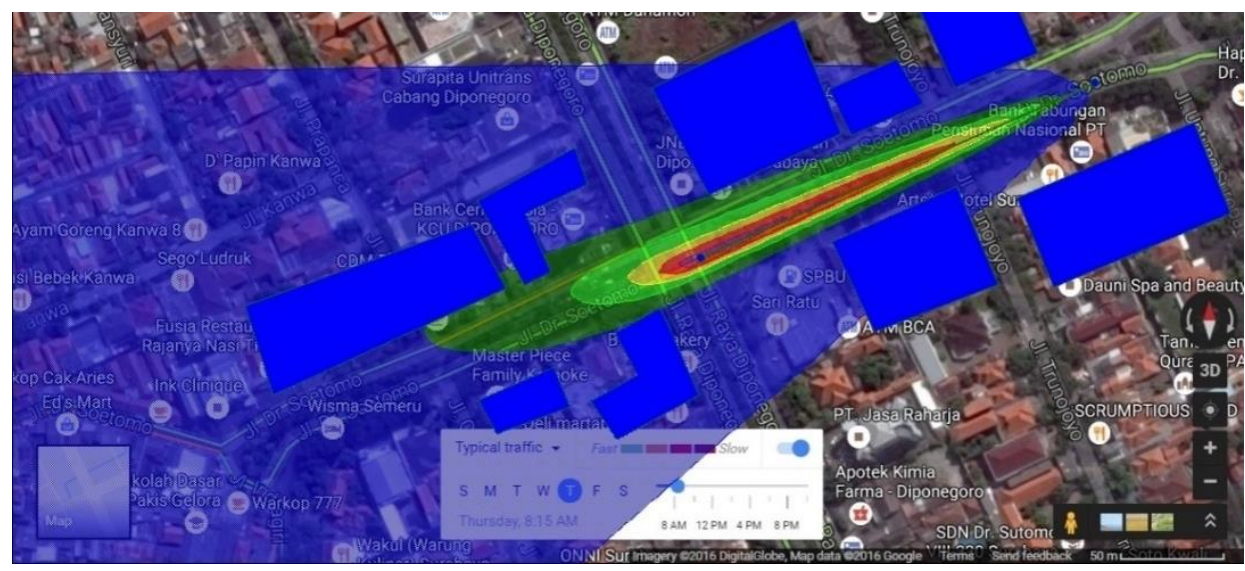

Sumber: Hasil Analisis, 2016

Gambar 9. Peta Konsentrasi $\mathrm{SO}_{2}$ di Jalan Dr. Soetomo

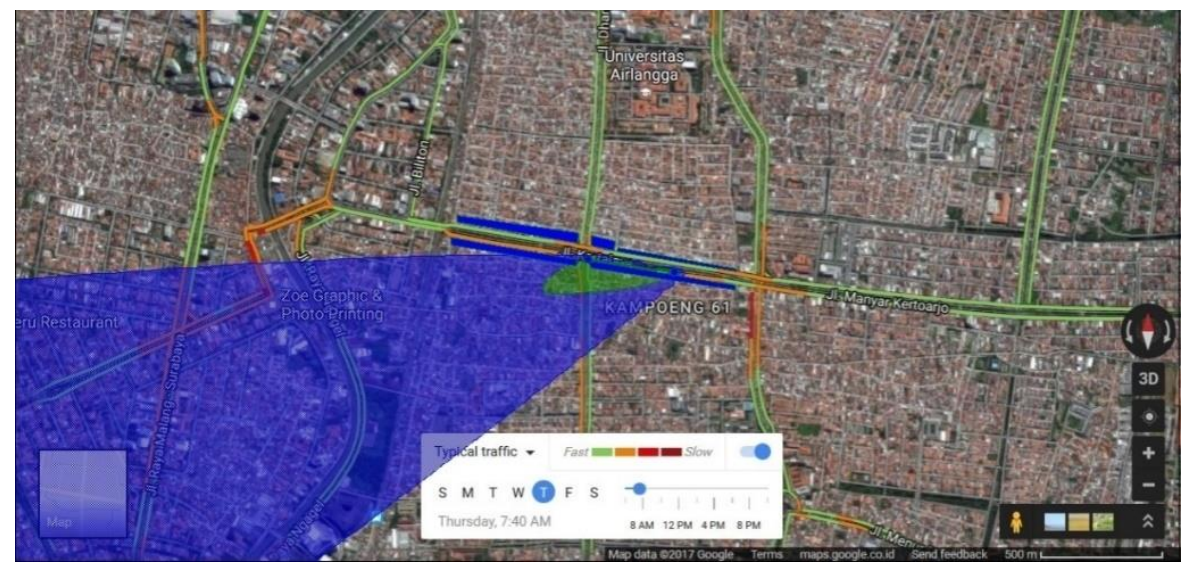

Sumber: Hasil Analisis, 2016

Gambar 10. Peta Konsentrasi $\mathrm{SO}_{2}$ di Jalan Kertajaya

\begin{tabular}{|c|c|} 
Legends : Unit [ug/m3] & Legends : Unit [ug/m3] \\
\hline $0.005-5$ & $0.005-50$ \\
$5-15$ & $50-500$ \\
$15-25$ & $500-1000$ \\
$25-50$ & $1000-1500$ \\
$50-75$ & $1500-2000$ \\
$75-$ & $2000-$ \\
\hline
\end{tabular}

Sumber: Hasil Analisis, 2016

Gambar 11. Keterangan Besar Konsentrasi $\mathrm{NO}_{\text {dan }} \mathrm{SO}_{2}$ 
Konsentrasi gas buang tersebut sangat besar, sehingga kualitas udara pada area penelitian berada di atas ambang batas yang ditetapkan oleh World Health Organization pada tahun 2005, dengan jumlah $\mathrm{PM}, \mathrm{NO}$, dan $\mathrm{SO}_{2}$ yang dihirup dalam waktu sehari masingmasing tidak boleh melebihi $50 \mu \mathrm{g} / \mathrm{m}^{3}, 40 \mu \mathrm{g} / \mathrm{m}^{3}$, dan $20 \mu \mathrm{g} / \mathrm{m}^{3}$.

Dampak dari emisi gas buang kendaraan terhadap kesehatan manusia telah diteliti oleh Boman, Forsberg, Järvholm, Scandinavian, \& August (2003), yang menyatakan bahwa terdapat hubungan yang sangat erat antara tingkat kematian, penyakit asthma, dan gangguan pernapasan terhadap daerah yang dilalui kendaraan dengan volume $\mathrm{NO}, \mathrm{SO}_{2}$, serta $\mathrm{PM}$ tinggi. Penelitian oleh Lee, Kim, \& Lee (2014) menemukan hubungan antara meningkatnya kadar konsentrasi PM di lingkungan dan penyakit kardiovaskular, tekanan darah tinggi, serta tingkat kematian tinggi. Risiko kesehatan yang terjadi bagi manusia yang menghirup emisi gas buang sangatlah tinggi (Bourdrel, Bind, Béjot, Morel, \& Argacha, n.d.; González-Díaz, Arias-Cruz, Macouzet-Sánchez, \& Partida-Ortega, 2016; Kim et al., 2017; Liu et al., 2017; Schultz, Schauer, \& Malecki, 2017). Hal ini membahayakan bagi pengendara sepeda motor yang sering terekspos emisi gas buang di daerah persimpangan. Biaya perawatan kesehatan juga akan meningkat akibat meningkatnya penyakit kardiovaskular pada masyarakat (Heidenreich et al., 2011). Hal-hal tersebut dapat dihindari apabila syarat desain persimpangan dikaji ulang.

\section{Kesimpulan}

Konsumsi BBM kendaraan dalam keadaan diam (idle) sangat signifikan dibanding konsumsi BBM saat mobil bergerak atau berakselerasi. Pada durasi lima menit antara jam 8.25 hingga 8.30, konsumsi akibat antrian kendaraan dalam keadaan diam di salah satu persimpangan di Surabaya Tengah (di Jalan Dr. Soetomo) mencapai 30 liter, sedangkan konsumsi BBM kendaraan dalam keadaan bergerak dengan kecepatan rata-rata yang rendah yaitu sebesar 5,8 km/jam adalah sebesar 19 Liter. Total konsumsi BBM selama dua jam di satu perempatan bila dibandingkan dengan konsumsi rata-rata di kota Surabaya adalah sebesar $0,03 \%$.

Konsumsi BBM yang cukup besar juga menghasilkan emisi $\mathrm{CO}_{2}$ yang tinggi. Meskipun lampu lalu-lintas sanggup mengatur volume lewatan mobil menjadi relatif lancar, namun jika terjadi antrian akan menghasilkan emisi $\mathrm{CO}_{2}$ yang signifikan, yaitu sebesar 152 ton hanya dalam periode waktu lima menit.

Emisi gas buang $\mathrm{NO}, \mathrm{SO}_{2}$ yang dihasilkan oleh kendaraan jauh melebihi angka keamanan yang disarankan oleh World Health Organization (2016), sehingga emisi gas buang sendiri perlu mendapat perhatian yang serius.

\section{Daftar Pustaka}

Aubé, F. (2001). Guide for Computing CO2 Emissions Related to Energy Use, 4(1), 2-4. Retrieved from www.marcobresci.it/docs/guida_co2.pdf.

Badan Pusat Statistik Indonesia. (2014). Statistik Transportasi Darat. Jakarta.

Boman, B. C., Forsberg, A. B., Järvholm, B. G., Scandinavian, S., \& August, N. (2003). Adverse health effects from ambient air pollution in relation to residential wood combustion in modern society. Scandinavian Journal of Work, Environment \& Health, 29(4), 251-260. Retrieved from https://www.ncbi.nlm.nih.gov/pubmed/12934718.

Bourdrel, T., Bind, M.-A., Béjot, Y., Morel, O., \& Argacha, J.-F. (n.d.). Cardiovascular effects of air pollution. Archives of Cardiovascular Diseases. doi:10.1016/j.acvd.2017.05.003.

Dispenda Kota Surabaya. (2010). Jumlah Kendaraan Bermotor di Surabaya. Surabaya.

Dragomir, C. M., Constantin, D.-E., Voiculescu, M., Georgescu, L. P., Merlaud, A., \& Van Roozendael, M. (2015). 


\section{Kajian Emisi Kendaraan di Persimpangan Surabaya Tengah dan Timur serta Potensi Pengaruh...}

Modeling results of atmospheric dispersion of NO2 in an urban area using METI-LIS and comparison with coincident mobile DOAS measurements. Atmospheric Pollution Research, 6(3), 503-510. doi:10.5094/APR.2015.056.

González-Díaz, S. N., Arias-Cruz, A., Macouzet-Sánchez, C., \& Partida-Ortega, A. B. (2016). Impact of air pollution in respiratory allergic diseases. Medicina Universitaria, 18(73), 212-215. doi:10.1016/j.rmu.2016.10.006.

Google Maps. (2016). Jalan Kertajaya dan Jalan Dr. Soetomo. Retrieved April 19, 2016, from https://maps.google.com/.

Hadis, C. S., \& Sumarsono, A. (2013). Hubungan Tundaan dan Panjang Antrian terhadap konsumsi bahan bakar akibat penutupan pintu perlintasan kereta api (Studi kasus pada perlintasan kereta api di Surakarta). Matriks

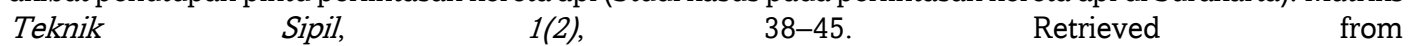
http://matriks.sipil.ft.uns.ac.id/index.php/MaTekSi/article/view/47.

Heidenreich, P. A., Trogdon, J. G., Khavjou, O. A., Butler, J., Dracup, K., Ezekowitz, M. D., ... Woo, Y. J. (2011). Forecasting the future of cardiovascular disease in the United States: A policy statement from the American Heart Association. Circulation, 123(8), 933-944. doi:10.1161/CIR.0b013e31820a55f5.

Higashino, H., Mita, K., Yoshikado, H., Iwata, M., \& Nakanishi, J. (2007). Exposure and risk assessment of 1,3butadiene in Japan. Chemico-Biological Interactions, 166(1-3), 52-62. doi:10.1016/j.cbi.2006.10.002

Ismayanti, R. I., Boedisantoso, R., \& Assomadi, A. F. (2010). Kajian emisi Co2 menggunakan persamaan mobile 6 dan mobile combustion dari sektor transportasi di Kota Surabaya. Retrieved from digilib.its.ac.id/public/ITS-Undergraduate-16090-3307100053-Paper.pdf.

Isnaeni, M., \& Lubis, H. A.-R. (2003). Efek Lingkungan Interaksi Transportasi Dan Tata Ruang Kota. Institut Teknologi Bandung.

Kim, I.-S., Sohn, J., Lee, S.-J., Park, J.-K., Uhm, J.-S., Pak, H.-N., ... Joung, B. (2017). Association of air pollution with increased incidence of ventricular tachyarrhythmias recorded by implantable cardioverter defibrillators: Vulnerable patients to air pollution. International Journal of Cardiology, 240, 214-220. doi:10.1016/j.ijcard.2017.03.122.

Lee, B.-J., Kim, B., \& Lee, K. (2014). Air pollution exposure and cardiovascular disease. Toxicological Research, 30(2), 71-5. doi:10.5487/TR.2014.30.2.071.

Liu, Y., Xie, S., Yu, Q., Huo, X., Ming, X., Wang, J., ... Shi, T. (2017). Short-term effects of ambient air pollution on pediatric outpatient visits for respiratory diseases in Yichang city, China. Environmental Pollution, 227, 116-124. doi:10.1016/j.envpol.2017.04.029.

Md Habib Al Razi, K., \& Hiroshi, M. (2012). Modeling of atmospheric dispersion of mercury from coal-fired power plants in Japan. Atmospheric Pollution Research, 3(2), 226-237. doi:10.5094/APR.2012.025.

National Oceanic and Atmospheric Administration. (2016). Surface Data Hourly Global DS3505. Retrieved August 21, 2016, from https://www7.ncdc.noaa.gov/CDO/cdopoemain.cmd.

PT. Binakarya dan SWEROAD. (1997). Manual Kapasitas Jalan Indonesia (MKJI). Jakarta

Schultz, A. A., Schauer, J. J., \& Malecki, K. M. C. (2017). Allergic disease associations with regional and localized estimates of air pollution. Environmental Research, 155, 77-85. doi:10.1016/j.envres.2017.01.039.

Suhadi, D. R., \& Febrina, A. S. (2013). Pedoman Teknis Penyusunan Inventarisasi Emisi Pencemar Udara Di Perkotaan. Jakarta.

World Health Organization. (2005). International Health Regulations. World Health Organization. Retrieved from http://www.who.int/ihr/publications/9789241596664/en/.

World Health Organization. (2016). World Health Statistics - Monitoring Health for the SDGs. World Health Organization. Retrieved from http://www.who.int/gho/publications/world_health_statistics/2016/en/. 